\title{
'Worden als een kind'. Als welk kind?
}

\author{
Harry E Faber van der Meulen \\ Dordrecht, Nederland
}

\begin{abstract}
'Becoming like a child'. Like what child?

'Becoming like a child' is an idea often expressed in the New Testament in connection with the following of Jesus. However, the meaning of this phrase is not so clear. It has to be understood in its cultural context. The author seeks to clarify that cultural context by discussing the culturerelated views of childhood in biblical - especially New Testament times as these are refelcted in biblical, Qumran and early rabbinic literature.
\end{abstract}

\section{INLEIDING}

'Wie zich niet bekeert en wordt als een kind, zal het rijk van God niet kunnen binnenkomen ...'

'Wie het rijk van God niet ontvangt zoals een kind, zal er niet binnenkomen ...'

'Wie een kind als dit bij zich opneemt, neemt Mij bij zich op en wie Mij bij zich opneemt, neemt Hem bij zich op die Mij gezonden heeft ... ‘... voor wijzen en verstandigen verborgen, maar aan kinderen geopenbaard ...'

'Wie is de grootste in het rijk van God? Die zichzelf gering acht als een kind, die is de grootste in het rijk van God'.

'Laat de kinderen tot Mij komen, houdt ze niet tegen, want voor hen die zijn zoals zij, is het rijk van God'.

Heel bekende woorden van Jezus, zo bekend, dat we al toestemmend knikken voordat we deze klanken tot ons laten doordringen.

* Hierdie artikel is 'n verwerking van die Fensham Gedenklesing wat dr Harry E Faber van der Meulen gelewer het as deel van sy verpligtinge terwyl hy in 1995 in diens was van die Departement Ou Nabye Oosterse Studie van die Universiteit van Stellenbosch. 
Deze woorden van Jezus kunnen we op twee manieren opvatten, om zo te zeggen omarmen of van ons afduwen. Want: geloven als een kind. Wie zou dat niet willen? Een kinderlijk geloofhebben, is dat niet iets heel moois?

Wie zou dat niet willen? Een kinderlijk geloofhebben, is dat niet iets heel moois?

Maar ook: geloven als een kind? Zou een volwassene nou echt zo willen geloven? Een kinderlijk geloofhebben, is een volwassene daar niet aan ontgroeid? 'Geloven als een kind' is een manier van geloven, die nogal gemengde gevoelens kan oproepen. Is 'geloven als een kind' niet een beetje krampachtig, een beetje hunkeren naar 'vroeger toen alles nog goed was' en blijkt hieruit weer eens te meer, hoe in diepste zin geloven irreèl en onnozel is? Weer een kind worden en niet meer kritisch nadenken, niet meer je eigen mening hebben en niet meer verantwoordelijk zijn voor jezelf, maar in kinderlijke eenvoud, in kinderlijk vertrouwen en kinderlijke afhankelijkheid je openstellen voor God? Geloven als een vlcht uit deze werkelijkheid naar ee andere werkelijk-heid? Wie probeert te geloven moet zich kompleet anders gaan gedragen en dus niet meer volwassen zijn of doorstoten naar de volwassenheid, maar als het ware andersom gaan leven, als het ware terug in de tijd? Is dat eerlijk, is dat echt, is dat gezond?

Wie niet wijs wil zijn, wie niet nadenkt, wie zijn verstand op nul zet is de ware gelovige? En zowel gelovigen als nietgelovigen maken gretig gebruik van deze gevolgtrekking uit een woord van Jezus. De nietgelovige kan nu met recht zijn schouders ophalen over de onzinnige tegenstelling, die hier wordt geconstrueerd tussen je verstand gebruiken en kind-zijn. Want deze woorden leiden toch tot in wezen het einde van elke menselijke en dus ook culturele vooruitgang? Wie kind wil blijven kan zich toch niet handhaven in het leven? Kind-zijn is toch ook maar een fase van het mens-zijn en zit in elk kind ook niet de drang om volwassen te worden? Wie het kind-zijn voor zijn leven bepalend maakt, zinkt toch af tot een samenleving die de onnozelheid aanprijst als dat, waar het in het leven uiteindelijk om gaat?

En een gelovige kan - op zijn beurt - zich nu met gemak allerlei kritische, via het intellekt ontwikkelde, aanvallende vragen en opmerkingen van het vrome lijf houden, want staat er niet geschreven, dat kennis en wijsheid voor het geloof geen funktie hebben, dat kennis en wijsheid je van het geloof afhouden en dat intellekt en geloven elkaar bijten? Juist wie geen kennis heeft, juist wie min of meer 'onnozele dingen' denkt en juist wie niet zo goed geoefend is, geeft door zijn 'nietweten' een blijk van diepe vroomheid. Een echte gelovige kan maar beter dom zijn - of zich van de domme houden - dan met behulp van zijn kritisch nadenken te proberen zijn geloof gestalte te geven. En de gelovige bidt: o God ik dank U, dat ik zo dom ben?

In het jaarlijks voorgelezen kerstverhaal kun je dan nog horen: ... en je zult een kind vinden in doeken gewikkeld en liggend in een kribbe ... Wat aan te vangen met zo'n kind? Maar gelukkig dat kind is volwassen geworden. En nu net deze Volwassene zegt: wie het rijk van God niet ontvangt als een kind zal er niet binnen kunnen komen. 


\section{GELOVEN ALS EEN KIND VAN NÚ?}

Al deze opmerkingen en vragen in verband met 'geloven als een kind' en 'kinderlijk geloven' hebben als belangrijkste oorzaak onze verlegenheid met woorden van Jezus over zijn of worden als een kind. Deze verlegenheid heeft waarschijnlijk als corzaak, dat wij niet meer direkt en zuiver kunnen navoelen, wat Jezus met zijn beeldspraak heeft bedoeld. Om die reden is er bij de uitleg van zijn woorden veel ruimte voor onze eigen opvatting over een kind. En dan kan het niet anders of wij dragen allerlei meningen over het kind vanuit de twintigste eeuw binnen in een tekst, uitgesproken en opgeschreven in de eerste eeuw.

Daarnaast bestaat altijd het gevaar, dat over de menselijke binding met God over religie dus - heel romantisch, heel vriendelijk en voorzichtig wordt nagedacht, zodat in wezen elke schok vanuit de religie door de romantiek wordt ontkracht." Terwijl door de romantische aanpak van 'geloven als een kind' velen zich ook vervreemd voelen van Jezus' woorden. Onze tijd denkt niet meer zo sterk romantisch over de binding tussen God en mens, tussen een hemelse vader, die alles weet en ik als kind, die daarmee tevreden kan zijn. Hoe zou het ook kunnen na twee wereldoorlogen, concentratiekampen, locale oorlogen over de hele aardbol, milieuvergiftiging en menselijke overbevolking? Dat niet-weten, dat zoete niets, die hele kinderlijke onnozelheid, het past niet in onze tijd. Maar paste het wel in de tijd van Jezus? Wat heeft Hij gedacht bij zijn beeldspraak over kinderen en wat hebben de omstanders eruit gehoord en geleerd? 'Geloven als een kind', als welk kind?

\section{WORDEN ALS EEN KIND}

Overigens van 'geloven als een kind' heeft Jezus nooit gesproken! s veıgсus vmucu we een tekst in de trant van: wie niet gelooft als een kind zal het rijk van God niet binnenkomen.

'Geloven als een kind' en allerlei variaties zoals 'kinderlijk geloven', 'naïef geloven' of 'niet kritisch, maar als een kind geloven' zijn wel heel gangbaar onder gelovigen - en vaak afgewezen door nietgelovigen - maar door Jezus niet onder woorden gebracht!

Het is ook niet .korrekt om uitsluitend zijn woorden over 'aanvaarden als een kind' op te vatten vanuit de 'psychologie van het kind'. Te overwegen valt, of Jezus' beeldspraak niet meer naar de bedoeling van de spreker wordt begrepen, wanneer zijn woorden als volgt worden uitgelegd en vertaald: wie het rijk van God niet aanvaardt als (-of hij) een kind (was)... Trouwens nu past de weergave helemaal bij Jezus' andere woorden om te worden als een kind! Ook is duidelijk, dat het in de eerste plaats van belang is er achter te komen, hoe in Jezus' tijd het kind werd bekeken met volwassen ogen. 
Wanneer Jezus een kind naar voren schuift, terwijl Hij zijn woorden spreekt over bekering en worden als een kind, moeten we ons voorstellen dat Hij gewezen heeft op een jong kind. Hoewel de exakte leeftijd nooit helemaal te achterhalen is - vooral ook omdat in zijn tijd anders onderscheiden wordt dan in deze tijd - bedoelt Hij zeker niet - zoals wij dat noemen - een halfvolwassene. Halfvolwassenen van nu waren in Jezus' tijd doorgaans al getrouwd en behoorden dan in feite meer tot de wereld van de volwassenen.

In Jezus'tijd worden allerlei ervaringen en opvattingen over mensen - klein en groot - bepaald door wat het Woord van God en de vroegjoodse traditie over hen hebben te zeggen. Hoe ligt nu de verhouding tussen kind en volwassene in het verlengde van wat we kunnen lezen in het Oude of Eerste Testament en de vroeg-joodse en rabbijnse traditie?

\section{KIND IN HET EERSTE TESTAMENT.}

In het Eerste Testament wordt van kinderen gesproken in hun verhouding tot ouders en opvoeders. Het hebreeuws kent zo een kleine tiental woorden, die wij met 'baby', 'klein kind' of 'kind' vertalen, terwijl in deze taal ook van het woord 'kind' gebruik wordt gemaakt als omschrijving voor iemand die bij een groep hoort of als leerling tegenover een leraar staat (het gaat dan om het verschil tussen 'kind' en 'gemeenschap' of 'kind' en 'oudere'). Tenslotte kan het ook om een sociaal verschil gaan, dat wil zeggen het woord voor 'kind' wordt dan vertaald als knecht, als slaaf, dus als iemand die afhankelijk is van een familie.

In het hebreeuws en ook in het grieks kan met de uitdrukking 'kind' dus' zowel een persoonlijk afhankelijke als een sociaal afhankelijke verhouding omschreven worden. Meteen kan nu worden vermoed, dat de positie en de waardering van het kind in de joods-hellenistische wereld van Jezus een ander accent heeft dan in onze tijd. Kind-zijn betekent in die tijd: onderdeel-zijn, afhankelijk zijn en bijna onpersoonlijk zijn. Want het kind is wel van belang, maar dan als 'nieuwe generatie' en als de zekerheid dat een familienaam behouden blijft. Het kind heeft slechts aandacht binnen een groter geheel, dat wil zeggen als behorend bij een familie, een stam, een volk.

Het zogenoemde 'eigene' of typische van een kind valt niemand op, omdat het 'eigene' en typische van een kind geen funktie heeft'. Het kind hoort bij een familie, een stam, een volk en van het kind wordt verwacht dat hij of zij een waardevol lid van die familie, van die stam en van dat volk wordt. Een kind moet dus opgevoed worden, want een kind 'als kind' heeft alleen betekenis voor zover volwassenen zich ermee bezighouden om het kind voor te bereiden op zijn volwassen-zijn. 


\section{VAN HET EERSTE TESTAMENT NAAR BEN SIRA}

Het kind is kostbaar in die zin, dat via het kind het geslacht in stand blijft en de vader voortleeft. In de tweede eeuw $\mathrm{v}$ Chr schrijft een joodse wijsheidsleraar dan ook: wie zijn zoon goed opvoedt, zal er wel bij varen en zal zich op hem kunnen beroemen in de kring van zijn bekenden ... Is de vader van die zoon overleden, dan is hij toch niet gestorven, want hij heeft zijn evenbeeld nagelaten (Sir 30:2, 4).

Sterke nadruk ligt op de volwassene, die zichzelf terugvindt in zijn kind. Die een 'evenbeeld', een 'gelijke' ( $\dot{o} \mu \hat{i}_{0} \varsigma$ ) nalaat! Het krijgen van kinderen wordt als een zegen van God ervaren en kinderloosheid als een straf van Gods kant. Zo gauw het kind de wereld binnenkomt, wordt het met de ogen van volwassenen bekeken, gemeten en becordeeld. De 'waarde' van een kind ligt in het feit, dat er een 'waardevolle' volwassene uit kan groeien. Wanneer bijvoorbeeld de profeet Elisa door een groep kinderen uitgescholden wordt van wege zijn kale hoofd, vervloekt de profeet hen en prompt komen twee beren uit het bos en verslinden 42 van die kinderen ( 2 Kon 2:2325). De woede van de profeet op deze kinderen is opvallend en tevens het feit, dat de bestraffing uiterst radikaal is.

Hierachter zit een bepaalde opvatting over wat een kind is en hoe het zou moeten zijn. Het kind is een volwassene in wording en moet streng worden aangepakt om een waardevolle volwassene te kunnen worden. En de weg waarlangs iemand volwassen wordt is vol gevaren en het grootste gevaar is zo'n kind zelf. Er heerst een grote mate van argwaan tegenover het kind als zodanig en deze houding van afstand en kontrole wordt religieus gevoed door het verhaal in Genesis over de zondvloed.

\section{EEN MENS IS ZONDIG VANAF ZIJN KIND-ZIJN}

Het zondvloed-verhaal in Genesis eindigt met een zelfgesprek van God: $l k$ zal de aarde niet meer vervloeken om de mens, want wat de mens vormt in zijn hart is kwaad vanaf

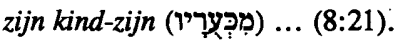

Zo is overigens het verhaal over de zondvloed ook begonnen: toen de Heer zag, groot is het kwaad van de mensen op de aarde en alles wat hij vormt in de gedachten van zijn hart is slechts kwaad elke dag weer ....(6:5).

Alles waaraan de gedachten van zijn hart vorm geeft is kwaad. Hier wordt een woord voor vormgeven gebruikt (יער) - dat vormen of boetseren kan betekenen -, en dat we ook tegenkomen in het tweede scheppingsverhaal: en God 'vormde' - boetseerde - de mens van leem van de aarde (2:6).

Dus er bestaat een tegenstelling tussen God als 'vormgever' en de mens als 'vormgever'. God vormt de mens, er ontstaat iets goeds (eerste scheppingsverhaal) en de mens vormt en kwaad ontstaat. De goede Vormgever staat tegenover de kwade 
vormgever en deze laatste is kwaad vanaf zijn kind-zijn (נפר). Hij vormt kwaad in zijn hart heeft een kwade neiging (יצר הרצ) vanaf zijn kind-zijn aan (vgl Jer 3:25 en Stuart 1984). In cen joodse hervertelling van de bijbel uit de eerste eeuw wordt dan ook net deze passage naar voren gehaald en weergegeven binnen het verhaal van de auteur: ... want de neiging van het mensenhart is dwaas vanaf zijn jeugd (Pseudo-Phil, LAB 3, 9).

En daarom lezen we in het Spreukenboek ook als reden waarom deze spreuken zijn verzameld (1:2vv.):

... om te leren wijsheid en discipline om te begrijpen woorden met een diepe inhoud om terechtwijzing aan te nemen, die verstandig maakt

- wat is goed, hoe moet ik mij gedragen, wanneer ben ik eerlijk om te geven inzicht aan onervarenen aan een kind kennis en vorming.

Een kind heeft geen inzicht en is onervaren, het ontbreekt een kind aan kennis en vorming. En hoe waar in het algemeen deze omschrijving ook is tegelijker-tijd moet ook een negatieve komponent worden gehoord, dat juist de macht van het kwaad bij de opvoeding tot wijze volwassene zich breed kan maken.

Dus wordt in het boek Spreuken er grote nadruk op gelegd, hoe hardleers kinderen zijn:

Voed je zoon goed op en maak zijn juk zwaar; anders struikel jij zelf nog over zijn onbehouwenheid

(Spr 30:13)

Aan een kind moet weinig of geen vrijheid worden gegeven, want anders kan het kind niet goed 'gedresseerd' worden tot een volwassene (Sir 30:8).

Wie de roede niet gebruikt, houdt niet van zijn kind, maar wie hem liefheeft straft hem vroegtijdig

(Spr 13:24)

Het kan al vroeg mis gaan met een kind, je kunt niet vroeg genoeg met bestraffen beginnen.

Stokslagen en terechtwijzingen maken iemand wijs, maar een kind, dat aan zichzelf wordt overgelaten, maakt zijn moeder te schande 
Ook aan God zelf wordt deze strenge benadering toe geschreven:

... want God gebruikt de roede voor wie van Hem houdt, zoals een vader dit doet met de zoon die hij liefheeft

(Spr 3:12)

We komen uitspraken tegen als de nek van het kind buigen en dat gaat zover, dat kan worden gezegd:

$\ldots$ breek hem de ribben zolang hij nog jong is

(Sir 30:12)

In de verhouding tot opvoeders en leraars is er geen enkele belangstelling voor wat wij het 'eigene' en typische van het kind - of van een kind - zouden noemen. De hele kinderpsychologie, die ons beinvloedt, was toentertijd in feite ondenkbaar. In de verhouding tot opvoeders en leraars worden kinderen gezien als onopgevoed, onervaren en dom. In zoverre vormen kinderen een gevaar. Het kind staat tegenover de opvoeder als de 'domme' tegenover de 'wijze'. Een kind ontbreekt het aan elke vorm van inzicht. Als een straf van God beschouwt de profeet Jesaja - naast het wegnemen van elke ervaren leider zoals profeet, rechter, kapitein - dat onervarenen de leiding zullen krijgen, dat kinderen bepalen wat gebeurt (3:4):

Ik geef hun kinderen als hun heersers, die nog aan het spelen zijn als hun meesters.

Stel dat jonge mensen het roer in handen krijgen, dan wordt willekeur koning. Pas op voor jonge mensen ${ }^{2}$.

Maar is het ook niet zo, dat in de joods-hellenistische tijd toch minstens de 'onschuld van het kind' waardevol werd geacht? Zeker hebben de mensen van toen de 'kinderlijke onschuld' herkend en ook erkend, maar heel algemeen gesteld: ze hebben het kind niet als een 'grootheid op zich' beschouwd, niet zo geidealiseerd als naderhand binnen onze kultuur de gewoonte is geworden. In de joods-hellenistische omgeving van Jezus is geen plaats om aandacht te besteden aan het kind 'als kind', laat staan aan het kind toegedachte karakter-eigenschappen te verheerlijken! Het joodse kind heeft zich te voegen naar de wensen van ouders en leraars.

Van de twaalfjarige (!) Jezus vertelt de evangelist Lukas, dat hij uit Jeruzalem met zijn ouders naar Nazareth terugkeerde en hun gehoorzaam was. En daarna voegt Lukas een opmerking toe - die helemaal past in het opvoedingskader van toen - : en Jezus werd met de jaren wijzer en wijzer ... (2:51, 52). 


\section{HET KIND IN ENKELE TEKSTEN VAN QUMRAN}

In deze samenhang is het van belang om na te gaan, of ook materiaal uit Qumran nog een extra dimensie kan toevoegen aan onze kennis over het kind tegenover volwassenen binnen het vroege jodendom.

Zoals bekend zijn er verschillende 'Regels voor de Gemeente' gevonden in Qumran, die als leefregels voor een afgescheiden groep esseense - of misschien sadducese — joden worden beschouwd (vgl Garcia Martinez \& Van der Woude 1994 (Inleiding) en die teks in Charlesworth 1994). In hun 'Regel voor de Gemeenschap' lezen we (1QSa 2, 3vv):

... Maar, ieder die door een of andere menselijke onreinheid is getroffen zal niet in de bijeenkomst van God binnentreden.

En niemand die is getroffen door de volgende afwijkingen zal een plaats vinden binnen de Gemeenschap: iedereen die getroffen is in zijn lichaam, vergroeid wat betreft zijn voeten of handen, lam of blind of doof of stom of is getroffen door een afwijking in zijn lichaam, die voor de ogen zichtbaar is; of een oude man, die zo trilt, dat hij zich niet staande kan houden binnen de Gemeenschap -

Al dezen mogen niet binnnenkomen om te staan in de Gemeenschap van de mannen van naam, want (כיא) heilige engelen zijn in hun Bijeenkomst aanwezig ...

Vooral de laatste zin is veelzeggend: omdat heilige engelen aanwezig zijn wanneer de 'mannen van naam' bijeenkomen, daarom mag geen gebrekkige toegang hebben tot hun bijeenkomst. De afgescheiden Qumran-gemeente bereidde zich overigens voor op een eindgericht, waarin de 'zonen van het Licht' en de 'zonen van de Duisternis' tegenover elkaar zouden staan. In de zogenoemde Oorlogsrol vinden we een beschrijving van hen, die mee mogen optrekken vanuit de Gemeente om te strijden tegen de 'zonen van de Duisternis'. De tekst luidt als volgt (1QM 7, 3vv):

Maar, geen enkel kind (נצר), jongeling of vrouw mag in hun legerplaatsen komen, wanneer zij uittrekken uit Jenuzalem om ten strijde te trekken, tot hun terugkeer. En niemand, die hinkt, blind of lam is of iemand, die een'blijvend gebrek aan zijn lichaam heeft, of iemand die getroffen is door een onreinheid van zijn lichaam - al dezen zullen niet samen met hen in de oorlog gaan. Allen moeten zijn mannen bereid tot de strijd en volkomen van geest en lichaam en bereid tot de dag van de wraak. 
Maar, ieder die niet rein is vanaf het moment, dat hij zich in de bron reinigt op de dag van de oorlog, mag niet met hen meetrekken, want de heilige engelen zijn samen één (יחר) met hun legers.

Deze keer op het hoogtepunt van een eschatologische beschrijving van de overwinning van de 'zonen van het Licht' - de leden van de gemeenschap van Qumran - tegen de 'zonen van de Duisternis - 'de anderen' - wordt nadrukkelijk vermeld, dat ook geen kind aanwezig mag zijn binnen de groep van 'reinen en zuiveren', die ten strijde trekt. Een kind is geen 'zoon van het Licht', is niet zuiver en rein en dat op grond van het feit, dat het kind 'kind' is. In feite een direkte tegenstelling met onze opvattingen over het kind-zijn binnen onze maatschappij (vgl Malina 1993 eindnoot 2; die overigens deze voorbeelden niet noemt!). Er komt nog bij, dat de regels over onreinheid en over wie wel of niet in staat van reinheid verkeert ons uit het OT goed bekend zijn (vgl Num 5:1-4; Lev 13:46 (melaatsen); 21:16 (mensen met een lichaamsgebrek); Deut 15:21; 23:18 e v; 2 Sam 5:6-8 (blinden en lammen)). Maar niet eenmaal is terug te vinden een zo stringente regel, die ook betrekking heeft op het kind. En de reden voor deze absolute mate van reinheid - waarbij kinderen en anderen met welk gebrek ook uitgesloten zijn - is, dat heilige engelen een eenheid met hen vormen. En zoals in de raad van 'de mannen van naam' heilige engelen aanwezig zijn en daarom geen enkele gebrekkige of hulpbehoevende bejaarde mag binnenkomen net zo mag een kind niet mee optrekken als 'zoon van het Licht' tezamen met de heilige engelen.

Intussen is gedurende de laatste jaren binnen het nieuwtestamentisch onderzoek een grotere aandacht voor vroeg-joodse apocalyptische en mystieke teksten aan het groeien. En dan gaat het niet alleen om apocalyptische teksten als de Openbaring van Johannes, maar ook om een onderzoek, dat teksten betreft, die kennelijk ontstaan zijn onder invloed van apocalyptische en mystieke gedachten binnen het vroege jodendom (Rowland 1994:506).

\section{MATTHEUS 18:1-10 EN HET KIND IN QUMRAN}

Keren wij nu terug naar de ons zo bekende woorden van Jezus over 'worden als een kind'. In Mattheus 18 (1-10) vragen de leerlingen Jezus: wie is de grootste in het rijk van God? Jezus schuift een kind naar voren en zegt: wie zichzelf gering zal achten als dit kind, die is de grootste in het koninkrijk der hemelen ... (4). Het kind zou de maat van ware grootheid moeten zijn. In het vervolg spreekt Jezus over een kind als volgt: wie één van deze kleinen, die in Mij geloven, tot zonde verleidt, het zou beter voor hem zijn, dat een molensteen om zijn hals was gehangen en hij verzwolgen was in de diepte van de zee (6). En de verwarring bij zijn toehoorders neemt toe. Natuurlijk is het slecht een mens tot 'zonde te verleiden' en dus ook een kind, maar een mens is toch geneigd tot alle kwaad vanaf zijn kind-zijn? Een kind is toch al 'zondig'? 
Jezus vervolgt nu zijn betoog met een scherpe wee-uitroep over de wereld en een lijst van zwart-wit formuleringen over de gevaren, die mensen kunnen lopen in dit leven en dan zo maar volgt een merkwaardige uitspraak (10): En denk er aan, veracht niet één van deze kleinen, want Ik zeg $u$, dat hun engelen in de hemelen voortdurend het aangezicht zien van mijn Vader, die in de hemelen is.

$\mathrm{Er}$ is iets heel bijzonders met een kind - en de omstanders happen naar adem en begrijpen er niets van - vanuit de apocalyptische verhalen weten ook zij van enkele engelen, die het grootste voorrecht bezitten wat er bestaat: de visio Dei. Het zien van God, gezeten in zijn glorie op een troon. Stervelingen kunnen hierop hopen, maar noch de mensen noch - doorgaans - de engelen kunnen direkt God zien. Maar van de engelen van 'de kleinen' vertelt Jezus, dat deze zo vlakbij de troon van God staan, dat zij God kunnen zien in zijn glorie. God zien van aangezicht tot aangezicht. Het kan het diepste verlangen van een mens zijn en is aan het einde van de bijbel (Op 22:4 en 5) als het einde der tijden als volgt omschreven, dat de bewoners van het nieuwe Jeruzalem, dat uit de hemel op de aarde is neer gedaald, Gods aangezicht zullen zien en zijn naam zal op hun voorhoofden zijn en er zal geen nacht meer zijn en zij hebben geen licht van een lamp of het licht van de zon nodig, want de Here God zelf zal hen verlichten...

Wat Mattheus hier beschrijft is een direkte relatie tussen kinderen en engelen, die God zien, die verlicht worden en dit herinnert er aan, hoe Jezus enkele hoofdstukken eerder had gezegd (1 1:25): ... Ik dank $U$ Vader, Heer van de hemel en de aarde, dat $U$ deze dingen voor wijzen en verstandigen hebt verborgen maar aan kleine kinderen

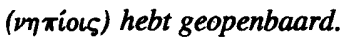

En dat zijn nu die kinderen, die volgens de 'Regel van de Gemeenschap' in Qumran juist er niet bij horen, omdat engelen aanwezig zijn! Jezus draait precies om, wat in Qumran gedacht en gedaan wordt.

\section{VROEG-RABBLJNSE DISKUSSIE OVER HET KIND}

Tegen deze achtergrond moet ook nog worden gewezen op de vroeg-rabbijnse diskussies over het feit, of een klein kind al het onderscheid tussen goed en kwaad kent, of dat de 'neiging tot het kwade' en de 'neiging tot het goede' zich later bij een kind ontwikkelen. De verschillende vroeg-rabbijnse uitleggers geven verschillende antwoorden, maar zijn het er wel over eens, dat God beide neigingen in een mens in plant. Eén van de problemen is dan bijvoorbeeld: op welke leeftijd ontwikkelt zich de 'neiging tot het kwade' bij een kind.

Als min of meer algemeen aanvaarde opvatting is de mening geworden, toegeschreven aan Rabbi Jehoeda (tweede eeuw n Chr), vaak Rabbi genoemd. Hij vormt zich zijn opinie door een twistgesprek met Antoninus. Antoninus vraagt zich af: wan- 
neer begint de 'neiging tot het kwade' macht over een mens te krijgen, is dat meteen als hij geformeerd wordt als embryo, of pas vanaf het moment van zijn geboorte? Het antwoord van Rabbi is: vanaf het moment van ontstaan als embryo.

Daarop reageert Antoninus met de overweging, dat van geen enkel kind in de buik van de moeder 'kwade neigingen' bekend zijn, dus komt een mens pas onder 'kwade invloed' wanneer hij geboren wordt. Dan zegt Rabbi: Antoninus heeft gelijk en ik ben dank zij hem wijzer geworden. Daar komt nog bij, wat hij zegt is ook in overeenstemming met wat in de Tora geschreven staat (Gen 4:7): de zonde ligt als een belager voor de deur. Als deur wordt dan door Rabbi opgevat - in deze samenhang - de opening van de moeder, waardoor de baby naar buiten komt.

Zoals zo vaak in de rabbijnse traditie bestaat er een variant van dit verhaal. Ook bij deze variant is Rabbi het met Antoninus eens, maar als tekst uit de Tora - waarop Rabbi uiteindelijk zijn mening baseert - wordt nu de door ons reeds aangehaalde woorden van Gen 8 (:21) genomen: want de neiging van het hart van een mens is kwaad van jongs af aan (vgl de diskussie tussen Rabbi en Antonius in Gen R 34, 10 en Sanh 91b).

Toch - voor zover ons bekend eenmaal - wordt deze gedachte anders onder woorden gebracht in een oude midrasj op psalm 8:3, waar het volgende wordt gezegd over de relatie tussen God en kinderen: Toen God van plan was aan Israël de Tora bekend te maken als een weergave van het verbond, dat Hij wilde sluiten met zijn volk, vroeg Hij eerst of de mensen Hem ook enige garantie zouden kunnen geven, dat zij van hun kant de verplichtingen van dit verbond - neergelegd in de Tora - zouden nakomen. Toen wezen de mensen op de 'verdienste van de vaderen'. (זכות אכות) dat wil zeggen: het goede leven en de goede daden van de aartsvaderen Abraham, Izaak en Jakob werden aangeboden als een garantiebewijs, dat zij - als nakomelingen van deze drie - zeker aan hun verbondsverplichtingen zouden voldoen. Maar God was van mening, dat de aartsvaders niet alleen maar goed geleefd en goed gehandeld hadden en dat zij dus niet voldoende 'verdienste' hadden opgebouwd. Na een lang gesprek tussen God en de mensen boden zij uiteindelijk hun kleine kinderen aan en God ging hiermee accoord.

Meteen kwamen de ouders met hun kinderen aan de borst naar voren - ook de vrouwen die zwanger waren - en God vroeg aan de kinderen: willen jullie garant. staan voor je ouders, dat zij zich zullen houden aan de Tora, die Ik van plan ben aan hen te openbaren? En willen jullie de straffen op je nemen, wanneer jullie ouders zich niet aan de Tora houden? Alle kinderen - zowel die net geboren waren als die nog in de buik van hun moeder zaten - antwoordden: ja!

Dan volgt de bekendmaking, de openbaring van de Tora. En God zei: Ik ben de Heer jullie God, en de kinderen antwoordden: ja. Daarna zei Hij: je zult geen andere goden aanbidden en de kinderen antwoordden: ja. Zo reageerden alle kinderen met 
'ja' als het ja moest zijn en met 'nee' als het nee moest zijn. Want er staat geschreven in het woord van God: uit de mond van kinderen, zelfs van de allerkleinsten heb Ik kracht gevormd (Ps 8:2). Met het woord 'kracht' is, volgens de rabbijnen, niets anders bedoeld dan de Tora, want er staat in Gods woord: de Heer zal zijn volk kracht verlenen (Ps 29:11). Als Israel zijn leven niet inricht volgens de Tora, vraagt God genoegdoening van de kinderen. Dit betekent dat de straffen die in de Tora voorgeschreven staan - wanneer iemand de voorschriften niet opvolgt - op de kinderen neerkomen. Want er staat in Gods woord: ... omdat je de Tora van je God vergeten hebt, zal ook Ik je kinderen vergeten (Hos 4:6). Daarom stierven er zoveel kinderen toen Israel zich niet aan de Tora wilde houden.

Zelfs de 'verdienste van de aartsvaderen' - belangrijke volwassenen als Abraham, Izaak en Jakob - geeft God niet de zekerheid dat hun nageslacht in staat zal zijn op een zuivere manier met de Tora om te gaan. Ook al noemen zij zich 'kinderen van Abraham' God vertrouwt op de werkelijke kinderen, zowel geboren als ongeboren. Deze laatste toevoeging past in de lijn van de diskussie over de vraag wanneer de kwade neiging macht krijgt over een mens. Dat toch reeds geboren kinderen 'meedoen' toont aan, dat de opvatting over de slechtheid van een mens 'vanaf zijn jeugd aan' ook minder absoluut kan gehanteerd worden binnen de rabbijnse traditie.

Er wordt in de diskussie van de rabbijnen nadruk op een mogelijke 'onschuld' van het kind gelegd, maar deze wordt steeds gebruikt ter vergelijking met volwassen menselijk gedrag en de vraag wordt onderzocht: in hoeverre hebben kinderen in hun 'onschuld' reeds deel aan het goede en het verkeerde in het menselijk gedrag op zichzelf. En ook hier gaat het niet om de 'onschuld' van het kind op zichzelf, behalve in het laatste voorbeeld, waarbij het concept van de 'verdienste van de vaderen' wordt gezet tegenover de 'verdienste van de kinderen' in die vorm, dat God en kinderen een direkte verbinding met elkaar blijken te hebben op het gebied van geloven en werken (ivm זכות בנים vgl Schechter 1969:311 - voor de vertaling van de Midr Wünsche 1967 en Ginsberg 1968:89-90).

\section{KORTE SAMENVATTING}

Het kind wordt in het Ou Testament en in de joods-hellenistische traditie van Jezus' tijd als volkomen afhankelijk van zijn omgeving, als een 'volwassen mens in wording' ervaren (vgl Garnsey 1991:48-65). Het kind is dus als mens onaf en inkompleet. Een vader kan blij zijn met zijn kind, wanneer hij dit kind als evenbeeld kan achterlaten, wanneer hij zelf sterft.

Vanaf zijn geboorte staat het onder invloed van de 'neiging tot het kwade'. Zonder de volwassenen is een kind niet in staat snel en goed volwassen te worden - te leren om te gaan met zowel de 'neiging tot het kwade' als die tot 'het goede' in de voetstappen van vader te gaan en als zelfstandig persoon zich te gedragen. 
In streng afgescheiden kring wordt het kind gelijk gesteld met elke volwassene, die als 'onrein' kan worden gekwalificeerd, in het bijzonder wanneer de 'reine groep' met engelen samenkomt.

Het kind moet leren wat de juiste weg in het leven is en afwijkend of onzorgvuldig gedrag betekent automatisch tegen een door God gewilde orde tussen ouderen en jongeren ingaan. Het kind mag dankbaar zijn dat er volwassęnen zijn en kan zijn dank gestalte geven door er voor te zorgen snel en waardig zich als volwassene te gedragen, want in het volwassen worden ligt de waarde van zijn bestaan hier op aarde. Dat betekent een grote zorg voor kinderen van de kant van de ouderen - in de klassieke tijd waren de joden bekend om het feit, dat zij geen kinderen te vondeling legden!* maar de zorg van de ouders gaat er naar uit dat de kinderen worden zoals de ouders zijn.

\section{1. 'WORDEN ALS EEN KIND' VOLGENS MATTHEUS EN VOLGENS LUKAS}

Wie zichzelf gering acht zoals een kind, die zal belangrijk zijn in het rijk van God (Mat.18:4). Wees er van verzekerd, wie zich niet bekeert en wordt als de kinderen, zal niet het rijk van God kunnen binnenkomen (18:3). Jezus spreekt hier van bekering en de inhoud van die bekering is: worden en zijn zoals een kind in zijn onbelangrijkheid.

Zo weinig als een kind 'als kind' voorstelt, zo weinig als een kind van zichzelf denken kan en denken mag, zo klein en zo nederig heeft een gelovige zichzelf te zien en zich zo te gedragen? Bekeren betekent in feite: je zus of zo gedragen, opdat jij opvalt bij God? Klein moeten zijn en je nederig moeten voelen en waarschijnlijk ook nog dankbaar?

Maar het gaat niet in de eerste plaats er om, wat een gelovige zou moeten doen of welke goede - al dan niet kinderlijke - indruk hij zou moeten maken. Het gaat in de woorden 'van Jezus om het kind-zijn van elk mens, het gaat om een ontologie en niet om een psychologie, het gaat om een zijns-kategorie. In aanvulling hierop zegt Jezus dan: wie een kind als dit bij zich opneemt, neemt Mij bij zich op (Mat 18:5).

\footnotetext{
* Tacitus (56-120) verteldt in Hist. 5,3 van de joden, dat bij hen necare quemquam ex agnatis nefas (het dooden van een later geboren kind een misdaad is). Ook bij Hekataeus van Abdera (ong. 300 v. Chr.) staat (volgens een citaat bij Doid. Sic. [B.H. 40, 8]) een opmerking, die in dezelfde ricting wijst: '... degenen, die in het land woonden verplichte hij (= Mozes) hun kinderen op te voeden ... . Het te vondeling leggen van later geboren (dus tweede, derde en zovoort) kinderen was heel gebruikelijk onder romeinen en grieken. Zogenoemde infanticide kwam om allerlei reden veel voor. En daarom legt Flavius Josephus - tijdgenoot van Jezus en Paulus - er as volgt nadruk op: 'Onze Wet schrijft voor, dat alle kinderen moeten worden opgevoed. Het staat een vrouw niet vrij om zich te laten aborteren of (het kind) om te brengen' (Ap. 2, 202).
} 
Bij de evangelist Mattheus is het duidelijk, dat hij in zijn beschrijving van Jezus gebruik maakt van een begrip, dat we uitvoerig beschreven vinden in de vroegrabbijnse en latere rabbijnse literatuur als 'Anawah' (nederigheid) (vgl Faber van der Meulen 1993:477-501; Kuhn 1968).

Door zijn levenshouding is Jezus - naar de beschrijving van Mattheus - te vergelijken met het kind in zijn tijd. Een kind kan worden genegeerd en gekoeieneerd, is afhankelijk en heeft geen invloed, wordt argwanend bekeken en als een troebele bron van narigheid beschouwd. Jezus verbindt zich nu met alle mensen die net zo over het hoofd worden gezien, zich niet zelfstandig kunnen handhaven en geen respekt van anderen ontvangen. In deze bijna negatie van hun bestaan zijn ze te vergelijken met het kind in Jezus' tijd. En tot grote hinder en frustatie van de gelovige mensen van zijn tijd noemt Jezus juist deze manier van mens-zijn de invalshoek voor God. Of andersom: God zoekt en vindt de gewantrouwden, afhankelijken, gekwetsten. Hij wordt door hen aangetrokken. Vandaar ook dat de evangelieschrijvers relatief veel aandacht besteden aan de genezingen van Jezus. Wanneer aan Jezus wordt gevraagd, of Hij nu de messias is op wie al zo lang wordt gewacht, verwijst $\mathrm{Hij}$ naar wat blinden, lammen, melaatsen, doden, doven en armen overkomt wanneer Hij hen ontmoet (Mat 11:5). Jezus zoekt dus juist mensen op die als arm en onbelangrijk worden beschouwd en dus zoekt Hij juist hen op, die in de gemeenschap van Qumran als onrein gelden.

Terwijl Mattheus grote nadruk legt op Jezus als de 'Nederige' en ook de beschrijving van 'worden als een kind' voor een belangrijk deel binnen deze kontext verder wordt uitgelegd, vinden we bij Lukas een toch wat andere mogelijkheid om de inhoud van 'worden als een kind' begrijpelijk te maken (vgl speciaal Fowl 1993:158). Het gaat om het bekende hoofdstuk 18, waarin wordt beschreven, hoe met behulp van de gelijkenis van de onrechtvaardige rechter en de gelijkenis van de pharizeër en de tollenaar een begin wordt gemaakt om aan te geven, wie zullen het 'rijk van God' kunnen binnenkomen. Niet een kenner van de wet als de pharizeër: Vervolgens weerhouden de leerlingen van Jezus de ouders om hun kinderen naar Jezus te brengen en Hij reageert met de opmerking: Laat de kleinen tot Mij komen en probeer hen niet tegen te houden, want voor hen is het 'rijk van God'. Werkelijk, wie het 'rijk van God'niet ontvangt, zoals een kind ontvangt, zal niet binnentreden $(16,17)$.

Daarop vraagt een rijke man: wat moet ik doen om het 'rijk van God' binnen te komen? Jezus antwoordt: verkoop alles wat je hebt. De rijke man denkt na en komt tot de veilige conclusie, dat het rijk van God voor hem toch wat te 'duur' is, wanneer het dat kost, wat geld in het bijzonder te bieden heeft: status en macht.

Vervolgens ontmoeten Jezus en zijn leerlingen een blinde, die roept om genezing en wanneer de omstanders hem vragen zijn mond te houden, gaat hij nog harder roepen. En Jezus reageert met een genezing en de woorden: jouw geloof heeft je gered (42). 
En dan in hoofdstuk 19 ontmoet Jezus de tollenaar Zachaeus. En Zachaeus reageert heel eenvoudig en heel spontaan en doet zwaarwegende stappen: hij geeft de helft van zijn bezittingen aan de armen en wie hij heeft bedrogen krijgt viermaal zijn geld terug. ' 'Redding is op deze dag in dit huis gekomen, is de reaktie van Jezus, want ook Zachaeus is een zoon van Abraham, en Ik ben gekomen om te zoeken en te redden wat verloren dreigt te gaan $(9,10)$.

Jezus' merkwaardige boodschap is deze: de toegang tot God loopt niet via inzicht en kennis in die zin, dat de pienteren een streepje voor zouden hebben, dat ontwikkelde kenners van wetten en regels, dat in het algemeen meer ervaren mensen als volwassenen er een beter zicht op zouden hebben, dat de zuiveren en reinen dichterbij God zouden staan, dat de voorzichtigen en rationeel denkenden uiteindelijk het bij het rechte eind zouden hebben. Ook aanzien en sukses beïnvloeden niet van Gods kant zijn verhouding tot een mens, de suksesvollen, de machtigen en de aanzienlijken zijn niet de door Hem gezegenden!

Wie God wil ontmoeten zal Hem alleen kunnen vinden 'als kind'. Dit betekent, dat in de relatie met God de bijbel verwacht van elk mens het kind te worden, dat hij is. Zou toch de vraag opkomen: wat moet ik doen in plaats van: wie moet ik zijn zou nu het antwoord kunnen luiden: word het kind, dat je bent. Alleen via deze weg is een relatie met God op te bouwen en alles, wat zweemt naar 'volwassenheid' stoort en vervreemdt een mens van zijn God.

\section{ACHTERGRONDEN VOOR JEZUS' GEBRIJK VAN DE BEELDSPRAAK 'WORDEN ALS EEN KIND'}

Welke woorden van het Eerste Testament hebben Jezus' opvattingen over worden als een kind eventueel kunnen beïnvloeden? In het Eerste Testament vinden we omschrijvingen voor God als vader of als moeder, en ook als vader en moeder. In het Eerste Testament komen deze omschrijvingen echter niet zo vaak voor ${ }^{3}$. Een van de oudste uitspraken over God-als-Vader komen we tegen in het 'Lied van Mozes', wanneer de relatie met God en de mens als individu - en tegelijkertijd ook als een deel van het volk Israel — wordt vastgesteld:

Hij is toch jouw vader, Hij heeft je verwekt.

$\mathrm{Hij}$ is het die jou gemaakt en het leven gegeven heeft (Deut 32:65) ${ }^{4}$.

Moeder wordt God nooit genoemd, niet in het Eerste en niet in het Tweede Testament. En we kennen niet een persoonsnaam, waarin God als moeder wordt omschreven. Betekent dit: onder het volk Israel is ooit gedacht aan de mogelijkheid van 'moederlijke gevoelens' bij God of een 'moederlijke kant' aan zijn zorg voor mensen? Integendeel! Mozes zegt tegen God (Num 1 1:12): 
Ben ik van heel dit volk zwanger geweest

of heb ik het ter wereld gebracht

en met deze woorden geeft hij indirekt aan, dat God door hem wordt opgevat als een 'moeder' voor het volk Israel. In een latere tekst wordt God vergeleken met een moeder onder mensen, wanneer in een profetie van Jesaja door God wordt gezegd (49:15):

Kan een vrouw haar zuigeling vergeten

een liefhebbende moeder het kind uit haar schoot?

En zelfs als die hun kind zouden kunnen vergeten,

Ik vergeet $\mathrm{u}$ nooit.

Daarmee stelt God zich nog moederlijker op dan een 'aardse' moeder, want in tegenstelling tot haar - vertelt de profeet - zal God zijn volk nooit uit het oog verliezen.

Zoals een moeder hem troost, zo zal Ik u troosten, ja in Jeruzalem zult $u$ getroost worden

(Jes 66:13)

De moederlijke bescherming van God blijkt ook uit een psalmtekst, waar de dichter schrijft:

immers ik heb mijn ziel tot rust en stilte gebracht

als een kind bij zijn moeder geborgen:

als een kind is mijn ziel in mij.

Laat Israel de Heer verwachten, van nu aan voor immer

God wordt hier vergeleken met een moeder, die haar kind tot bedaren brengt ${ }^{5}$. Ook kan God vergeleken worden met een vrouw die geboorte-weeën heeft:

lang heb Ik gezwegen, Mij stilgehouden en bedwongen:

nu kerm Ik als een vrouw die baren gaat,

Ik moet snuiven en hijgen tegelijk

(Jes 42:14)

Heel duidelijk laat de dichter-profeet merken - door het woord 'als' te gebruiken dat het niet gaat om een letterlijk te nemen tekst, maar om beeldspraak (vgl Jes 45:913). 
God wordt niet alleen vergeleken met een vrouw in barensnood, maar ook met een vroedvrouw. Het zijn enkele dichters en profeten die Gods bemoeienis met het begin van leven bij een mens heel nadrukkelijk onder woorden brengen. Zo kan een psalmdichter zeggen:

U haalde mij uit de schoot van mijn moeder

en legde mij veilig aan borst.

Aan U werd ik toevertrouwd, vanaf mijn geboorte bent u mijn God

(Ps 22:10, 11 - deze beeldspraak heeft bij de vorming van Jes 66:9 en Ps 71:6 een rol gespeeld).

De nadruk ligt niet zozeer op het feit of God nu te vergelijken is met een vrouw - en dan in het bijzonder een vroedvrouw - het gaat eerder om Gods verhouding tot mensen en zijn handelen met mensen, waarin van Gods kant zo grote zorg en hulp aangeboden wordt, vergelijkbaar met de hulp van een vroedvrouw bij de geboorte van een kind.

Hierop aansluitend, terwijl hij een stap verder gaat, kan een andere psalmdichter van God zeggen:

$\mathrm{U}$ weefde mij in de schoot van mijn moeder

$\mathrm{U}$ deed mij onstaan

(Ps 139:13)

Dit soort beeldspraak kan ook op het hele volk Israel worden overgebracht en dan lezen we bij Jesaja: zo spreekt God, uw Maker, die u gevormd heeft van de moederschoot af ... (44:2 en 24). En even verder voert de profeet God sprekend in met de woorden:

Luister naar Mij, huis van Jacob; en al wat er rest van het huis van Israel;

opgetild werden jullie vanaf de moederschoot

en sinds de geboorte gedragen.

Tot aan je oude dag blijf Ik, God, dezelfde, cok als jullie oud en grijs zult worden zal Ik je optillen, Ik heb het gedaan en Ik blijf je dragen, Ik zal je optillen en Ik zal voor je zorgen $(46: 3,4)$. 
Volgens Jesaja blijft God zich inzetten voor zijn volk en Hij blijft hen als kinderen benaderen en blijft hen als kinderen beschermen. En zelfs als zij 'oud en grijs'zijn geworden zal Hij hen optillen, dragen en verzorgen. Is God degene, die in een mens aldoor het kind blijft zien?

God fungeert als een vader en een moeder zegt een psalmdichter:

al hebben mijn vader en moeder mij verlaten, toch zult $\mathrm{U}$, o Heer, bij mij blijven

(Ps 27:10)

En steeds verder ontwikkelt zich het beeld van het volk Israel 'als een kind' met God 'als vader en moeder'. Zo vertelt de profeet Jesaja:

want de Heer heeft zijn volk getroost, $\mathrm{Hij}$ is begaan met zijn arme kinderen. Zion zei: 'De Heer heeft mij verlaten, de Heer is mij vergeten'.

'Vergeet een vrouw soms het kind aan haar borst, is zij niet begaan met haar bloedeigen kind?

En zelfs al zou zij haar kind vergeten, Ik vergeet jou nooit' $(49: 13 b-16)^{7}$.

Er blijkt een onverbreekbare band te bestaan tussen God en zijn volk 'als kind'. De diepste omschrijving hiervan is te vinden onder de profetieën van Jesaja in de 'Ephraimspreuk';

(Dit zegt de Heer) ...

Ephraim, je bent toch mijn lievelingskind, de zoon van wie Ik het meeste houd?

Telkens weer als Ik jouw naam noem, denk Ik aan je met tederheid, met diepe ontroering en Ik wil je helpen (31:20).

God kan niet loskomen van zijn 'kind', want zijn volk ontroert Hem zoals een kind zijn vader en moeder ontroeren kan. Vader en moeder komen in beweging en willen uiting 
geven aan die band, die er is en blijft tussen ouders en kind. Zo kan Jesaja ook de volgende woorden van God weergeven:

zo zegt de Heer:

Zoals men water naar een stad leidt

- het water van een volle beek --

zo leid Ik de vrede naar Jeruzalem, naar Sion de rijkdom van de volken

en dan zul je zuigen,

je zult op de heup gedragen

en op de knieën worden gekoesterd.

Zoals een moeder troost,

zo zal Ik je troosten $(66: 12,13)$.

Hoogtepunt binnen deze beeldspraak over Ood als vader en moeder tegenover Israel als kind vormen de innige woorden, die God volgens de profeet Hosea spreekt:

toen Israel nog een kind was heb Ik het liefgekregen,

Ik heb hem uit Egypte geroepen en mijn zoon genoemd ...

Ik leerde Israel lopen en nam hem op de arm.

Maar ze wilden niet erkennen, dat Ik hen verzorgde.

En toch leidde Ik hen met zachte hand

en voerde hen liefdevol mee.

Als ouders die hun kind opbeuren

om het tegen hun wang te drukken,

zo was Ik voor hen.

Ik boog mij naar hen toe en Ik gaf hun te eten.

(Hos 11:1-4)

\section{KORTE SAMENVATTING}

Israel is 'als een kind' en God kan niet loskomen van dat 'kind'. Zijn verbinding met mensen of zijn bemoeienis met mensen of zijn interesse voor mensen begint heel vroeg. Met behulp van begrippen als 'verwekken', 'laten geboren worden' - zie ook noot 14 -, 'uit de schoot van de moeder halen' en 'weven in de schoot van mijn moeder' proberen dichters en profeten te omschrijven, hoe intens God met zijn volk verbonden is vanaf het prille begin. Tussen God en Israel bestaat een band, die van Hem uit onver- 
brekelijk blijkt te zijn! En het is hier, dat Jezus aansluit met zijn woorden over 'worden als een kind'. De beeldspraak uit het Eerste Testament over Israel als kind en Gods verhouding tot Israel als kind wordt nu door Jezus verbreed en toegepast binnen een ruimer kader, toegepast op elk mens in zijn kind-zijn.

\section{PSALM 8 OVER HET KIND}

En nu komt iets heel uitzonderlijks: in die relatie van als een kind-zijn tegenover God, schrijft de bijbel een enorme kracht toe aan het kind. Van deze 'macht van het kind' vinden we al een enkele tekst in het Eerste Testament. Het gaat om een poëtische en een profetische tekst, zijn dichters en profeten bij uitstek in staat de 'macht van het kind' onder woorden te brengen? De dichter van psalm 8 (1-2) vertelt:

Hoe heerlijk, o God is uw naam op de hele aarde.

Want $\mathrm{U}$, die uw majesteit toont aan de hemel, hebt uit de mond van kinderen, zelfs van de allerkleinsten, $\mathrm{U}$ sterkte gevormd om met uw vijanden af te rekenen, om hen tot zwijgen te brengen en aan hun wraakzucht een einde te maken.

De dichter ziet als het ware de macht van God opkomen uit de mond van kinderen en zo kan God de kracht ontwikkelen om met zijn vijanden af te rekenen. Wat dan opvalt is het feit, dat deze beeldspraak uitgaat van de macht van God in samenhang met kinderen! Kinderen zijn er toch om opgevoed te worden tot flinke mensen, die dan misschien als 'Gods partner' het kwaad in het leven te lijf gaan? De dichter van psalm 8 zegt: ook een kind is 'Gods partner', ook een kind heeft kracht en macht en invloed. En God kan gebruik maken van het kind om een bolwerk op te richten tegen het kwaad.

\section{VAN MALEACHI VIA BEN SIRA NAAR LUKAS}

In deze samenhang kan ook een profetische tekst worden gezien. Een tekst, die vrij laat in het Eerste Testament wordt gebruikt, genoemd wordt in de 'tussen-testamentaire tijd' en vrij vroeg in het Tweede Testament nog een keer terugkomt. Het gaat om een tekst die in samenhang staat met de figuur van de profeet Elia. Binnen de joodse eschatologische verwachtingen speelt Elia een centrale rol als een profeet, die terugkeert in dit leven en de voorloper van de Messias zal zijn. Volgens de levensbeschrijving van deze profeet is hij niet gestorven, maar naar de hemel opgevaren (2 Kon 2:11- 
13 - vandaar dat Elia als hemelse gestalte verschijnt op de zogenaamde "berg van verheerlijking'samen met Mozes en Jezus: Matt 17:1-21; Mark 9:14-29; Luk 9:28-43). Wanneer de Messias zich openbaart zal de profeet Elia naar de aarde terugkeren om zijn komst aan te kondigen en voor te bereiden en - zo vertelt de profeet Maleachi:

Elia zal het hart van de vaders weer brengen tot hun kinderen en het hart van de kinderen weer brengen tot hun vaders $(3: 34 ; 4: 6)$.

Deze tekst over Elia wordt een paar eeuwen later - rond de tweede eeuw v Chr overgenomen door een wijsheidsleraar, wiens teksten als het boek Jezus Sirach zijn bewaard gebleven. Hier wordt van Elia gezegd, dat hij zal komen:

... om het hart van de vaders weer te brengen tot hun kinderen

(Sir 48:10)

De wijsheidsleraar geeft de tekst van Maleachi verkort weer in die zin, dat de harten van de vaders zich weer gaan bekommeren om de kinderen. Gelukkig maar voor de kinderen, dan kunnen zij weer wijsheid leren van de ouderen. En wijsheid leren is halacha en dat wil zeggen: 'gaan op de weg van de Tora', zoals die door de 'vaderen' is uitgelegd. En dit 'gaan op de weg van de Tora' is mogelijk dankzij onderzoek, inzicht en jarenlange ervaring.

De evangelist Lukas (1:17) heeft deze tekst van Maleachi gebruikt om aan te geven, dat Jezus als de Messias geboren is, terwijl Johannes als zijn voorloper - als de profeet Elia - fungeert. Een engel - zoals zo vaak in die tijd bij de geboorte van belangrijke mensen wordt beschreven - verschijnt aan de priester Zacharias en kondigt hem de geboorte van een zoon aan, die Johannes moet heten. Van deze zoon vertelt dan de engel, dat hij zal zijn als Elia:

om het hart van de vaders te brengen tot hun kinderen, de ongehoorzamen te leiden naar de gezindheid van de rechtvaardigen.

$\mathrm{Nu}$ heeft het citaat uit de profetie van Maleachi een heel andere wending gekregen! Eerst gaat het om een weergave, die we exakt zo bij Jezus Sirach terugvinden, maar dan volgt een parallellopende toevoeging, die het citaat zo uitlegt, dat het gaat om de harten van de vaders weer in liefde te laten kloppen voor hun kinderen en dat wil zeggen: hen die ongehoorzaam zijn te brengen bij hen die gehoorzaam zijn: hun kinderen. Die kinderen 'gaan op de weg' en 'zijn op de weg van God', terwijl de vaderen met hun wijsheid en hun uitlegging van de Tora - hun halacha en hagada - van de weg 
zijn geraakt! Geen schriftgeleerde, geen pharizeeër, geen sadduceeër, geen esseen uit Jezus' tijd.stokte niet de adem in de keel bij het horen van deze woorden. Om de mensen ontvankelijk te maken voor de messiaanse tijd zal van de vaders hun onjuiste houding worden bekend gemaakt en de kinderen zullen hun tot voorbeeld worden gesteld? Een mens, vanaf zijn kind-zijn geneigd tot alle kwaad, heeft stap voor stap zich ontwikkeld tot een 'wijze', een kenner van Gods wil, na jarenlange oefening weet hij hoe de neiging tot het kwade te onderdrukken '... en dan zo'n kind, zo'n troebele bron van narigheid zal hem tot voorbeeld zijn? Absoluut onmogelijk!

\section{DE MACHT VAN EEN MENS 'ALS EEN KIND'}

Een kind heeft macht, een kind is krachtig, een kind heeft aantrekkingskracht. Klein, onbelangrijk, gemakkelijk kapot te krijgen, onderontwikkeld, godsdienstig onzuiver, obstinaat, hulpbehoevend, spontaan en ondoordacht, maar daarin overmachtig en niet tegen te houden overtuigend. Overtuigend voor God.

God kan zich niet onttrekken aan mensen 'als kinderen'. Wie Hem zoekt moet worden 'als een kind', terwijl van zijn kant God aangetrokken wordt door iemand 'als een kind'. Het kind-zijn van een mens geeft toegang tot God en Hij komt tot mensen, die 'als een kind' zijn of proberen 'als een kind' te worden. De binding met God vanuit een mens loopt via zijn kind-zijn of kind-worden en God ziet in elk mens het kind, dat hij of zij is en kan niet nalaten een mens 'als een kind' op te vangen. Een mens - vertelt Jezus - wordt door God daar benaderd waar God en mens ontvankelijk zijn voor elkaar. En een mens zou er wijs aan doen op die weg te gaan, waar God zich laat vinden, waar Hij niet tegen een mens op kan, waar Hij een mens in zijn aantrekkingskracht wil ontmoeten.

'Als een kind' is een mens zoals Ik ben - vertelt Jezus van zichzelf - en Hij leefde met zo'u intense kracht dat zelfs de dood Hem niet kon vasthouden. Sterk als een kind leefde Hij, dus wordt Hij zoon van de Sterke, zoon van God genoemd.

En die kracht is anders en minder direkt in het ooglopend dan de gangbare manier van krachtig reageren bij mensen. Het gaat dan om een diepere kracht van binnen, die wel in elk mens zit, maar pas door de ontmoeting met God een mens zich herinnert en aan het werk zet in gezonde nederigheid en weerbaar maakt en met verwachtig vervult.

Elk mens blijft het kind dat hij eens was, elk mens blijft toegankelijk voor God en andersom: God wordt door elk mens 'als kind' aangetrokken. Dit aantrekkelijk zijn voor God maakt een mens tot een weerbaar mens, spontaan en direkt, en vol verwachting hoe het verder zal gaan. 


\section{Endnotas}

1 Voor een heldere weergave van dit probleem - een vergelijking met opvattingen over kinderen binnen de amerikaanse samenleving van nu en opvattingen uit de mediterrane tijd van 'het NT vgl Malina (1993:180-182). Wat overigens wel opvalt is het feit, dat Malina zoer schematisch denkt en bijna cen tegenstelling vermoedt tussen de tijd van nu en de tijd van toen!

2 Aan rabbi Dosa ben Harkinas (eerste eeuw) wordt de mening toegeschreven: 's morgens slapen, 's middags wijn drinken; kletsen met kinderen; en op ontmoetingsplaatsen zitten met domme mensen, brengt je orn je arndeel in deze en de toekomstige wereld $(A v 3,11)$.

3 In getallen ligt de verhouding tussen ongeveer 21 maal in het Eerste en 255 maal in het Tweede Testament! Het Eerste Testament - waar Jezus zich door laat inspireren - is duidelik nogal terughoudend in het gebruikmaken van de beeldspraak van God als Vader van personen of God als Vader van cen heel volk.

${ }^{4}$ De echo van deze oude tekst - God als vader van zijn volk Israel - vinden we terug in jongere geschriften zoals bij de profeten Jesaja $(63: 16 ; 64: 7)$ en Jeremia $(3: 4,9 ; 31: 9)$. Ook vinden we gedachten uit deze oude poetische tekst terug bij een jongere profeet als Maleachi, die de vraag stelt:

Hebben wij niet allen één vader.

Heeft niet éen God ons geschapen? (2:10a).

$\mathrm{Er}$ is nog een gering aantal teksten, dat indirekt herinnert aan Gods vaderschap en ook enkele persoonsnamen noemen God als vader. Vergelijk voor alle achtergronden van dit gedeelte van ons onderzoek, Korpel (1990:235-264).

5 Interessant is ook het feit, dat zich een beeldspraak heeft ontwikkeld, die zowel mannelijk als vrouwelijk kan worden vertaald. Het gaat om het hebreeuwse woord ילד dat 'verwekken'en 'geboren laten worden' kan betekenen. Een mooi voorbeeld van deze mannelijke en vrouwelijke mogelijkheid binnen zo een beeldspraak is psalm 2, waar de dichter zegt:

Hij zei tot mij: jij bent mijn zoon,

heden heb Ik jou verwekt/heb Ik jou laten geboren worden (7).

De gewoonte is om hier te vertalen: heden heb Ik jou verwekt - omdat wij ons doorgaans God als een man voorstellen-, taalkundig is de andere mogelijkheid even goed te verdedigen. En hetzelfde zien we bij de vrij oude tekst van het 'lied van Mozes', die als volgt luidt:

verlaten hebben jullie de rots die jullie heeft verwekt/

laten geboren worden,

vergeten de God die je heeft voortgebracht (Deut 32:18).

Hoogst waarschijnlijk heeft de dichter van dit 'lied van Mozes' zelf geen keuze gedaan, maar is er zich van bewust aan God op een figuurlijke manier gevoelens en daden toe te schrijven, ontleend aan de menselijke wereld van vader en moeder tegenover een kind! 
6 De profeet kan Gods vaderlijke en moederlijke gevoelens ook omschrijven op de volgende manier:

En God sprak:

Zij zijn mijn volk, mijn eigen kinderen, ze zullen Mij niet bedriegen.

Zo werd God hun verlosser.

In al hun benauwdheden was ook Hij benauwd ...

Hij kwam hen redden in eigen persoon.

Liefdevol en mild gestemd bracht Hij hun verlossing.

Hij nam hen op de arm,

Hij droeg hen al die lang vervlogen jaren $(63: 8,9)$.

Van deze vaderlijke en moederlijke zorg voor het volk Israel lezen we ook wanneer de profeet Jeremia God sprekend invoert met de verbaasde en geïrriteerde woorden:

volk van Israel, ooit heb Ik jullie gezegd:

'Julie zijn mijn kinderen

en een heerlijk land zaI Ik jullie geven,

mooier dan van enig ander volk'!

En Ik dacht: zeker zullen zij mij Vader noemen... (3:19).

\section{Literatuurverwysings}

Charlesworth, J H 1994. The Dead Sea Scrolls. Hebrew, Aramaic, and Greek Texts with English Translation. Rule of the Community and Related Documents. Tübingen: J C B Mohr.

Cohen Stuart, G H 1984. The Struggle in Man between Good and Evil. An inquiry into the origin of the Rabbinic concept of Yeser Hara. Kampen: $\mathrm{J} H$ Kok.

Dupont, J 1969. Les Béatitudes, II, La bonne Nouvelle. Paris: Gabalda.

Faber van der Meulen, H E 1993. Gods openbaring in Jezus als de 'Nederige': Mattheus' versie van de zaligsprekingen en een rabbijnse opvatting over 'Anawah', HTS 49, 477-501.

Fowl, S 1993. Receiving the Kingdom of God as a Child: Children and riches in Luke 18,15ff. NTS 39, 153-158.

Garnsey, P 1991. The Family in Italy from Antiquity to Present, in D L Kertzer \& P

Saller (eds), Child Rearing in Italy, 48-65. New Haven: Yale University Press.

Garcia-Martinez, P \& Van der Woude, A'S 1994. De rollen van de Dode Zee. Ingeleid en vertaald, Vol. I. Kampen: J H Kok.

Ginsberg, L 1968. Legends of the Jews, Vol III. Philadephia: Jewish Publication Society.

Haufe, G 1979. Das Kind im Neuen Testament. TLZ 104, 625-638 
Klein, G 1973. Bibelarbeit über Markus 10:13-16, in G Krause (Hrsg), Die Kinder im Evangelium, 12-30. Stuttgart/Göttingen: E. Klotz.Kraus, H.-J., Psalmen, I. (Neukirchen: Neukirchener 1978).

Kraus, H-J 1979. Theologie der Psalmen. Neukirchen-Vluyn: Neukrichener Verlag. Korpel, M C A 1990. A Rift in the Clouds. Münster: Ugaritverlag.

Kuhn, P 1968. Gottes Selbsterniedrigung in der Thologie der Rabbinene. München: Kösel Verlag.

Légasse, S 1969. Jésus et l'enfant. Enfants, 'petits' et 'simples' dans la tradition synoptique. Paris: Gabalda.

Malina, B J 1993. Die Welt des Neuen Testament. Kulturanthropologishe Einsichten. Stuttgart: Kohlhammer Verlag.

Roon, R G 1980. Het kind dat we waren en het kind dat we zijn. Kampen: J H Kok.

Rowland, C C 1994. Apocalyptic, the Poor and the Gospel of Matthew. JTS 45.

Schecter, S 1969. Aspects of Rabbinic Theology. New York: Schocken.

Stemberger, G 1979. Das klassische Judentum. München: Beck Verlag.

Van Boxel, P W 1994. De Wijsheid der Vaderen. Het Misjnatractaat Avot vertaald en toeglicht. Kampen: J H Kok.

Viviano, B T 1978. Study as Worship. Aboth and the New Testament. Leiden: E J Brill.

Weber, H-R 1979. Jesus and the Children. Biblical Resources for Study and Preaching. Geneve: WCC.

Wünsche, A 1967. Midrasj Tehillim. Hildesheim: Olms.

Zuurmond, R 1984. Het kind in de bijbel, in J. Doelman (red), Theologie op de groei, 73-83. Voorburg: Prot. St. Bev. Bibl en Litt. 